Volume 13 No 1 September 2017

\title{
KESUSASTRAAN: AJARAN NILAI-NILAI MORAL MASA HAMENGKUBUWONO V
}

\author{
Oleh: \\ Gandes Sekar Putri \\ Universitas Negeri Yogyakarta \\ Email: gandes.sekarputri@gmail.com
}

\begin{abstract}
ABSTRAK
Kajian mengenai nilai-nilai kepemimpinan Hamengkubuwono $\mathrm{V}$ dapat ditemukan pada karya-karya sastra yang berkembang pada masa itu. Karya sastra pada masa Hemangkubuwono $\mathrm{V}$ berkembang pesat dan mengandung ajaranajaran moral yang dapat menjadi acuan pada zaman sekarang. Salah satu karya sastra yang berkembang, yaitu Serat Jatipusaka Makutharaja yang berisi keteladanan seorang pemimpin dalam bertindak, nilai-nilai kepemimpinan sebagai bentuk keteladanan dan nilai-nilai kepemimpinan yang diimplementasikan dalam kehidupan. Kajian nilai kepemimpinan pada karya sastra dalam tulisan ini dapat disebut sebagai model kepemimpinan Jawa-Islam.
\end{abstract}

Kata kunci: karya sastra, nilai-nilai moral, Hamengkubuwono V

\begin{abstract}
The study of the values of leadership of Hamengkubuwono $V$ can be found in the literary works that developed at that time. The literary work of Hemangkubuwono $V$ period is growing rapidly and contains moral teachings that can be the reference of today. One of the emerging literary works, namely Serat Jatipusaka Makutharaja which exemplifies a leader in acting, values leadership as exemplary form and values of leadership that are implemented in life. The study of the value of leadership on literary works in this paper can be referred to as the Javanese-Islamic leadership model.
\end{abstract}

Keywords: literary works, moral values, Hamengkubuwono V 


\section{PENDAHULUAN}

Berdasarkan

Perjanjian

Giyanti pada 13 Februari 1755, maka terjadi pembagian wilayah kerajaan atau lebih dikenal dengan palihan nagari menjadi wilayah Surakarta Hadiningrat dan Ngayogyakarta Hadiningrat. Pada masa itu seni pertunjukan dan seni karawitan menjadi karya seni yang popular. Kemudian Sultan Hamengkubuwono I memberikan kesempatan para pujanggan untuk berkarya. Hasil karya sastra Kasultanan sebagian besar disimpan di Kawedanan Hageng Kridha Mardawa dan di Kawedanan Hageng Panakawan Widya Budaya (Lindsay, 1994: xixii). Perkembangan seni sastra mencapai puncak kejayaan pada masa pemerintahan Sultan Hamengkubuwono V (1822-1855 M).

Karya sastra yang tersimpan di Kawedanan Hageng Kridha Mardawa sebagain besar berkaitan dengan seni tari, yaitu srimpi, bedhaya, lawung, beksan pethilan, gendhing karawitan dan wayang. Sedangkan yang tersimpan pada Kawedanan Hageng Panakawan Widya Budaya terdiri dari sastra, babad, wayang, sejarah, silsilah, sasrta ajaran, sastra suluk, astronomi, primbon, pakuwon, bahasa dan tari (Lindsay, 1994: xi).

Masa pemerintahan Sultan Hamengkubuwono V merupakan masa paling sulit sebagai akibat jatuhnya kerajaan oleh serbuan tentara Inggris. Peristiwa penyerbuan disebut dengan geger spehi yang kemudian disusul dengan Perang Diponegoro (Dwiyanto, 2016: 7).
Akibat peristiwa tersebut beban politik dan sosial tidak dapat terelakkan di Kerajaan Ngayogyakarta Hadiningrat. Disisi lain pada bidang kebudayaan, khususnya kesusastraan dan kesenian mengalami kemajuan pesat.

Kesenian sastra tumbuh subur di lingkungan kerajaan, yaitu karyakarya ciptaan baru, salinan dan saduran (Marsono, 2004: 31). Pada karya ciptaan baru terdiri dari sastra wayang, suluk, primbon, babad, roman Islam dan bahasa. Karya salinan, antara lain kitab suci, sastra menak, sastra suluk, babad, silsilah, wayang, sastra piwulang, pakuwon, cerita kenabian, bahasa dan tari. Sedangkan pada karya saduran terdiri dari wayang, silsilah, babad, sastra menak, suluk, cerita kenabian dan sastra piwulang (Dwiyanto, 2016: 9).

Keadaan sosial dan politik yang kacau di wilayah kerajaan dapat terobati dengan peningkatan kualitas kesenian, kebudayaan dan kesusastraan. Karya sastra yang dihasilkan mengandung ajaran bernilai moral yang dapat digunakan sebagai acuan seiring terjadinya degradasi moral pada generasi muda pada zaman sekarang, sehingga karya sastra masa Hamengkubuwono $\mathrm{V}$ menarik untuk dikaji.

\section{KONDISI SOSIAL DAN POLITIK MASA HAMENGKUBUWONO V}

Hamengkubuwono V menggantikan ayahnya ketika masih berusia balita (tiga tahun). Pada saat itu pemerintah penjajahan Belanda berusaha membangun kembali 
kekuasaannya setelah diambil alih oleh pemerintah Inggris. Kepemimpinan Hamengkubuwono V pada masa kanak-kanak tidak dapat terlepas dari bayang-bayang Dewan Perwakilan dan tekanan Pemerintahan Belanda. Sultan Hamengkubuwono V memerintah dalam dua tahap yaitu pada tahun 1822-1826 dan 1828-1855. Lebih dari 120 karya sastra telah dihasilkan (Purwodinigrat, 2009: 255). Sultan Hamengkubuwono memberikan kepedulian berlebih pada perkembangan kebudayaan. Hal tersebut menggugah para seniman dan sastrawan untuk berkreasi.

Pasca Perang Dipanegara, pemerintah kolonial Belanda berhasil menguasai dan mengeksploitasi sumber daya di seluruh pulau Jawa (Ricklefs, 1995: 182). Dengan menerapkan kebijakan sistem tanam paksa, pemerintah kolonial Belanda dapat memperoleh keuntungan yang sangat besar. Antara tahun 18311877 pemerintah kolonial Belanda dapat melunasi hutang-hutang VOC dan mengirim uang kepada kerajaan Belanda sejumlah 832 juta gulden (Ricklefs, 1995: 187).

Adanya kekacauan kondisi sosial dan politik akibat kebijakan yang diterapkan pemerintahan kolonial Belanda, maka para elite kerajaan Jawa mengalihkan perhatian pada bidang seni dan budaya. Para pimpinan kerajaan di wilayah Jawa bagian tengah secara bersama-sama menjadi pelindung dan pendorong kegiatan dalam bidang kesusastraan. Bagi Sultan Hamengkubuwono V dengan banyaknya penulisan karyakarya sastra dapat memulihkan kembali koleksi perpustakaan
Keraton Yogyakarta yang telah dirampok oleh pemerintah Inggris (Dwiyanto, 2016: 73).

\section{KARYA-KARYA SASTRA MASA HAMENGKUBUWONO $\mathrm{V}$}

Sultan Hamengkubuwono $\mathrm{V}$
memiliki keungulan dalam
memprakarsai karya-karya sastra.
Adapun ciri-ciri dari 120 karya sastra
yang berhasil diprakarsai, antara lain:
1). Tulisan berbangun persegi, tegas
dan rapi seperti langgam masa Kartasura; 2). Penggunaan huruf besar (aksara murda) cukup banyak, seperti huruf $R a$ dan $N y a$ yang tidak dikenal di Surakarta sebelumnya; 3). Halaman, pupuh atau bagian-bagian naskah tidak bernomor; 4) Memiliki manggala (bait pembuka atau penutup) yang ditulis pada sepasang halaman yang berhias di depan maupun di belakang dan 5). Penggunaan sengkalan tidak hanya berfungsi melambangkan tahun tetapi juga untuk angka-angka lainnya (Purwodiningrat, 2009: 255261).

$\begin{array}{crr}\text { Karya } & \text { sastra masa } \\ \text { Hamengkubuwono } & \mathrm{V} & \text { dapat }\end{array}$ dikelompokkan dalam beberapa jenis karya, antara lain kesenian (karawitan dan tari), pewayangan, sejarah, agama dan ajaran. Babad Mentawis merupakan karya sejarah yang paling menonjol. Babad Mentawis ditulis sembilan kali, baik yang berdiri sendiri maupun cerita bersambung. Karya ini mencapai 3777 halaman yang terdiri dari cerita bersambung jilid I (364 hlm), jilid II (300 hlm), jilid III (362 hlm), jilid IV (358 hlm), jilid V (512 hlm), jilid VI 
(526 hlm) dan jilid VII (688 hlm), sedangkan pada Babad Mentawis yang berdiri sendiri berjumlah 361 halaman dan Babad Mentawis Ngayogyakarta berjumlah 306 halaman (Dwiyanto, 2016: 159).

\section{Karya sastra masa Hamengkubuwono V banyak dihasilkan pada tahun 1846 dan 1847 kemudian 1851. Salah satu karya sastra Hamengkubuwono $\mathrm{V}$ yang jarang dijumpai namun digarap serius yaitu mengenai ajaran (nilai- nilai kepemimpinan). Karya sastra yang berisi ajaran kepemimpinan, antara lain: Serat Makutharaja (1846), Serat Hastabrangta (1847) dan Serat Jatipusaka Makutharaja (1852). Karya sastra tersebut merupakan persepsi dan idealisasi Hamengkubuwono V mengenai kepemimpinan, selain sebagai reaksi dan kompensasi akibat tekanan politik pemerintah kolonial Belanda terhadap Keraton Yogyakarta.}

Para Wali Kerajaan yang mendampingi Hamengkubuwono V pada saat memimpin kerajaan di usia belia mengajarkan pengetahuan mengenai manajemen pemerintahan kerajaan. Pengetahuan mengenai kepemimpinan merupakan salah satu materi ajaran yang mempengaruhi jalan hidupnya. Sehingga pada saat memasuki usia dewasa, Hamengkubuwono V mendokomentasikan nilai-nilai kepemimpinan terebut dalam karya sastra. Secara monumental karya sastra tersebut terkumpul dalam Serat Jatipusaka Makutharaja. Intisari nilai kepemimpinan yang terdapat dalam Serat Jatipusaka Makutharaja adalah kemuliaan hati seorang raja yang memimpin kerajaan seperti Raja Yudhistira.

Sifat-sifat yang harus dimiliki oleh seorang raja, antara lain: tidak boleh melupakan bukari samsi narendra (asal usul perputaran leluhur raja), sukahar retna adi murti (wujud kehendak mulia dari leluhur) dan mengalir bagaikan aliran air sungai. Raja harus memiliki hati yang awas terhadap tajali atau penampakan Allah yang menyatu pada kalbu (hatinya) sehingga dapat memimpin dengan benar. Raja hendaknya selalu bergembira dalam mencari nafkah untuk hidup. Raja selalu berusaha meningkatkan pemahaman, berlatih dan berikhtiar memahami ajaran, percaya pada ilmu nyata dan menyimpannya di dalam hati (Dwiyanto, 2016: 164).

Secara ringkas Serat Suryanalendra berisi sanjungan pada keagungan Raja di Mataram sejak Kanjeng Panembahan Senapati. Raja disebut memiliki budi pekerti luhur dan cerdas sehingga sangat mempesona. Kemudian diceritakan secara berturut-turut sanjungan kepada Sultan Seda ing Krapyak, Kanjeng Sultan Agung, Sultan Agung Kreta di Mentawis, Kanjeng sultan Mangkurat Raja, Kanjeng Sunan Pakubuwono, Kanjeng Sultan Hamengkubuwono II, Kanjeng Sultan Hamengkubuwono III dan Kanjeng Sultan Hamengkubuwono IV. Serat ini juga menguraikan gambaran kesempurnaan hidup manusia dan mukmin yang sejati.

Kesusastraan merupakan salah satu penanda bagi sekelompok masyarakat yang telah memiliki peradaban tinggi. Karya sastra 
mengalami perkembangan pesat sehingga mendorong tumbuhnya jenis karya sastra baru yang memperkaya khasanah kesusastraan. Puisi dan prosa merupakan jenis kesusastraan yang telah dikenal secara umum. Dalam kesusastraan Jawa, bentuk puisi lebih dikenal dengan tembang atau nyanyian. Cara membaca puisi didasarkan atas patokan tertentu yang disebut guru lagu, guru wilangan dan guru gatra (Endraswara, 2006: 56).

Tembang Jawa banyak mengisahkan sejarah seorang tokoh ataupun kerajaan. Salah satu tembang Jawa Kuno adalah Kitab Negarakertagama karya empu Prapanca yang menceritakan sejarah Kerajaan Singosari dan Majapahit. Setelah mendapat pengaruh Islam, dunia kesusastraan lebih memiliki warna dan misi yang ada di dalamnya. Materi dakwah yang terdapat dalam tembang Jawa yaitu mengenai kehidupan manusia sejak dari dalam kandungan hingga wafat. Tembang-tembang Jawa yang menggambarkan siklus hidup manusia tersebut antara lain miji dan pocung.

\section{PENAFSIRAN KARYA SASTRA MASA HAMENGKUBUWONO V}

Dalam sejarah perkembangan peradaban Jawa, kesusastraan banyak memuat mengenai aspek kepemimpinan yang dianut para raja dan kaum bangsawan dalam memimpin rakyat. Seorang pemimpin dipandang dari perbuatan dan tutur kata yang mencerminkan keteladanan dan perjuangan. Nilai- nilai keteladanan dan perjuangan pemimpin mencerminkan pula budaya masyarakat yang mendukungnya (Setiadi, 2013: 57). Karya sastra pada umumnya berisi ajaran baik dan buruk. Konsep kepemimpinan astha-brata merupakan ajaran kepemimpinan yang terkenal, sebab banyak dicantumkan dalam karya sastra Jawa.

Konsep kepemimpinan asthabrata merupakan hasil penciptaan naskah-naskah dari konsep kepemimpinan dalam paham Hindu, yang menganggap raja merupakan perwujudan dewa. Raja yang ideal harus sakti, berwibawa, mulia dan dapat menguasai dunia dengan kekuatan dan aturan yang dimiliki. Perintah seorang raja merupakan hukum atau undang-undang yang harus dipatuhi dan dilaksanakan. Prinsip kepemimpinan astha-brata terdiri dari astha yang artinya delapan dan brata yang artinya keutamaan menggunakan prinsip kepemimpinan yang tercermin dalam sifat-sifat dewa lokapala (Susetya, 2007: 28).

Pada kitab kesusastraan yang dihasilkan saat ajaran Islam semakin kuat, simbol-simbol yang berasal dari aspek dewa-dewa dalam agama Hindu yang sudah dialihkan dengan simbol-simbol dari sifat unsur-unsur alam, selanjutnya lebih diperhalus lagi dalam karakteristik watak. Kedelapan sifat alam diubah menjadi delapan watak yang ditampilkan dalam wayang Wahyu Makutharama, yaitu: Laku Hambeging Kisma, Laku Hambeging Tirta, Laku Hambeging Dahana, Laku Hambeging Samirana, Laku Hambeging Samudra, Laku 
Hambeging Surya, Laku Hambeging Candra dan Laku Hambeging Kartika (Endraswara, 2006: 188).

Selain astha-brata, konsep kepemimpinan Jawa juga termuat dalam ajaran Sastra Cetha yang menyebutkan bahwa seorang raja harus dapat memahami tiga tingkatan nilai perbuatan, yaitu nistha (hina), madya (sedang) dan utama (terbaik). Perbuatan nistha harus dihindari, antara lain sikap kekhawatiran, bimbang, hanya ikut-ikutan dan tidak percaya pada anggota keluarga maupun pejabat kerajaan. Perbuatan madya cukup dengan dimengerti. Sedangkan perbuatan utama harus dilaksanakan berkaitan dengan segala hal.

Pada Sastra Cetha diajarkan bahwa tindakan yang baik harus jelas tujuan maupun sasaran, serta dilakukan dengan memperhatikan kesenangan orang lain. Beberapa macam perbuatan yang membahayakan dan menyusahkan yang harus segara ditumpas, yaitu pencuri, penculik, penyamun, penjudi, penjahat dan penjilat (Suyami, 2008: 103). Raja berkewajiban memperhatikan kehidupan rakyat, baik dalam kesejahteraan maupun mengenai penderitaan. Raja juga berkewajiban memelihara dengan baik para pendeta maupun resi dengan mencukupi segala kebutuhan. Para resi bertugas mendidik para warga yang berusia muda mengenai tindakan yang baik dalam mengabdi kepada kerajaan.

Perilaku budaya Jawa merupakan perbuatan susila yang memiliki sifat yang melekat pada hubungan dan perbutan antara manusia dengan norma budaya Jawa. Kitab-kitab suci dan karya sastra yang berisi ajaran moral, menekankan pentingnya seorang pemimpin untuk memahami hal-hal yang halal maupun haram dalam menjalankan pengabdian. Makna halal dan haram harus dipahami sebagai tindakan untuk tetap memperhatikan aturan yang ada sehingga dapat ditentukan tindakan yang diperkenankan dan tindakan yang dilarang (Dwiyanto, 2016: 180).

Pemimpin harus memiliki kemampuan dalam mengendalikan diri dari emosi yang berlebihan. Seorang pemimpin harus menjauhi sifat ketergesaan, ceroboh dan tidak teliti dalam pengambilan keputusan. Kualitas dalam pengambilan keputusan ditentukan oleh seberapa jauh pengendalian diri, sikap hatihati dan sikap tidak tergesa-gesa dari seorang pemimpin. Berfikir sebelum melakukan tindakan merupakan acuan bagi seorang pemimpin. Sikap ceroboh dalam bertindak akan berdampak buruk dalam pencapaian tujuan.

Seorang pemimpin haruslah dapat mengelola setiap konflik yang ada menjadi sebuah keberhasilan dalam mewujudkan tujuan yang hendak dicapai. Pemimpin harus bijaksana, berwatak sabar dan berani bertanggung jawab atas segala keputusan. Seorang pemimpin yang memiliki watak luhur akan berdampak pada rasa hormat bawahan terhdap pemimpin sehingga akan tercipta kewibawaan yang bukan berasal dari rasa takut (Dwiyanto, 2016: 81). 


\begin{abstract}
Keteladanan Panembahan Senopati dalam menjalankan kepemimpinan didokumentasikan dalam Serat Wedhatama. Sifat-sifat tercela yang dilakukan seorang pemimpin akan menjauhkannya dari kewibawaan, ketauladanan dan sebagai panutan. Dalam Serat Wulangreh, kepribadian seorang pemimpin, antara lain: 1). Pemimpin harus memahami halal dan haram; 2). Pemimpin harus bersikap sederhana; 3). Pemimpin harus loyal kepada negara; 4) Pemimpin tidak berwatak pedagang dan 5). Pemimpin harus rendah hati dan adil (Supeni, 2011: 64).
\end{abstract}

Seorang pemimpin harus menjauhi watak kesombongan. Kesombongan dapat berupa kesombongan fisik dalam menonjolkan kekuatan dan keberanian. Kesombongan harta yaitu menyombongkan kekayaan yang dimiliki dan kesombongan ilmu berupa kesombongan pribadi yang akan berdampak negatif terhadap suatu komunitas dengan bawahan. Seorang pemimpin akan lebih dihormati apabila dapat merendahkan diri daripada berwatak sombong. Watak dan pribadi yang baik akan menjadi teladan bagi para bawahannya.

Nilai-nilai kepemimpinan yang harus dimiliki oleh seorang pemimpin yaitu memiliki kemampuan mengendalikaan obsesiobsesi yang menguntungkan diri sendiri dan memperkaya diri melalui kekuasaan yang dimiliki baik secara struktural maupun sistematis. Pemimpin yang memiliki nafsu berlebihan dalam obsesi sehingga melanggar aturan, maka akan berdampak pada ketidakstabilan pada sebuah organisasi/kerajaan yang dipimpinnya. Rasa ikhlas perlu dimiliki oleh seorang pemimpin dalam menjalankan tugas. Keikhlasan dapat menumbuhkan rasa percaya diri seorang pemimpin dalam melaksanakan tugas yang diemban.

Ajaran yang bersifat etis spiritual terdapat dalam Serat Wedhatama. Nilai-nilai kepemimpinan yang terdapat pada bait-bait dalam serat yaitu sembah raga, sembah cipta, sembah jiwa, dan sembah rasa yang memiliki makna antara lain: 1). Agar segala kegiatan/aktifitas dapat dilaksanakan dengan baik maka seorang pemimpin harus mampu menjaga kesehatan dan vitalitas; 2). Dalam menghadapi tantangan seorang pemimpin harus dapat meningkatkan mental; 3). Dalam setiap aktifitas pemimpin harus mampu meningkatkan cita rasa (estetika) dan 4). Pemimpin harus dapat meningkatkan kemampuan spiritual, tunduk dan tawakal kepada Tuhan (Dwiyanto, 2016: 184).

Untuk mengembangkan diri maka seorang pemimpin diwajibkan menguasai ilmu pengetahuan. Pencarian ilmu harus terus menerus dilakukan oleh seorang pemimpin. Dalam melaksanakan kepemimpinan, seorang pemimpin tidak terlepas dari perjuangan yang tiada henti. Tapabrata dimaknai sebagai usaha spiritual yang kental terhadap kepercayaan bahwa apa yang menjadi tujuan dan obsesi segalanya tergantung pada Yang Maha Kuasa.

Kepustakaan mistik Islam kejawen berkembang pesat pada 
masa kerajaan Mataram Islam. Isi dari kepustakaan Jawa bertujuan untuk mempertemukan ajaran Islam dengan tradisi Jawa yang disebut dengan primbon, serat suluk dan wirid (Simuh, 1988: 9). Pada karya sastra yang terpengaruh tasawuf Islam telah berkembang sejak zaman kerajaan Demak. Pujangga-pujangga mistik Islam yang mewarnai corak sastra Jawa yaitu Al Ghazali dan Ibnu Arabi.

\section{Pada}

masa

Hamengkubuwono V karya sastra sangat bervariasi mulai dari moral, suluk, kepemimpinan dan olah seni. Ajaran yang menonjol di Kasultanan Yogyakarta adalah ajaran moral. Sultan Hamengkubuwono V memiliki andil dalam menciptakan karya sastra yang berisi ajaran kepemimpinan. Karya sastra berisi ajaran kepemimpinan yang dikenal pada masa Hamengkubuwono $\mathrm{V}$ salah satunya adalah Serat Jatipusaka Makutharaja. Makna nilai-nilai kepemimpinan dalam Serat Jatipusaka Makutharaja diharapkan dapat memberi gambaran mengenai kepemimpinan Hamengkubuwono V (Dwiyanto, 2016: 186).

\footnotetext{
Ajaran luhur yang terkandung dalam Serat Jatipusakan Makutharaja dapat menjadi tuntunan dan dilaksanakan dalam kehidupan berbangsa dan bernegara. Moral memiliki makna ajaran mengenai baik buruk suatu perbuatan, kelakuan, akhlak dan kewajiban. Moral juga berarti kesusilaan (Poerwadarminta, 1985: 654). Adapun kriteria perbuatan susila antara lain keputusan akal yang baik, kehendak baik dan penyesuaian
}

dengan hakikat manusia (Fudyartanta, 1974: 18).

Dalam Serat Jatipusakan Makutharaja pupuh Dhandhanggula pada 1 berisi ajaran mengenai keindahan, kebenaran dan kebaikan yang harus dipegang oleh seorang pemimpin. Adapun kutipan kalimat tersebut:

Irika tata kruding pangesthi manglunturing arju ginupita taseng iradat wijile pamerdiningreng masbun gebak toran cendhana minging tinrap ing tontro wistha prathisthaning sirtu winangun miruda raras kang winuni marasudaning narpati munggeng surya narendra

Terjemahan:

Raja yang adil adalah benar dalam berkuasa, tidak bersikap mendua, tidak melebihkan maupun mengurangi, tidak berada di depan maupun di belakang, tidak berada di luar atau di dalam, raja yang agung yaitu raja yang senantiasa melihat segala sesuatu dengan hati sehingga tahu yang benar dan yang salah anugerah dari Yang Maha Kuasa selalu terlimpah pada sang raja (Dwiyanto, 2016: 187)

Kesusastraan tergantung pada konvensi sosial budaya yang berlaku pada masyarakat tertentu (Teeuw, 1982: 9). Adapun yang dinamakan objek kesusastraan adalah objek yang dinamikanya ditentukan oleh syaratsyarat dan norma-norma kemasyarakatan yang berbeda-beda. Serat Jatipuaka Makutharaja pupuh Dhandhanggula pada 14 menggambarkan kewibawaan seorang raja yang memiliki kebijaksanaan, kemuliaan dan keindahan budi pekerti yang 
dihormati oleh seluruh rakyat. Adapun kutipan kalimat tersebut:

Sunan Mangkurat Mas pan winuni

sebak danu tan nawa tiksyana

endra marhatin arjune

tyas murla walu-walu

kyat wara sapata dipati

wasis sumbaga kennya

karem jupiteku

patistha ngraras wanodya

ngentha karsa pengpengan wilaya pati

destun yoga sumbaga

Terjemahan:

Diceritakan tentang Kanjeng Sunan Mangkurat Mas

raja yang dihormati oleh seluruh rakyat

segala sabdanya ditaati rakyat

raja yang tersohor karena kebijaksanaan

kemuliaan hati

dan keindahan budi pekerti

menumpas segala kejahatan

sehingga rakyat dapat hidup tenang dan damai

(Dwiyanto, 2016: 188)

Dalam sastra penggambaran sifat-sifat dan perilaku seorang pemimpin didasarkan pada tokoh pewayangan yang dijadikan teladan (Haryanto, 1992: 157). Salah satu karya sastra berupa tembang yang berkembang pada masa Sultan Hamengkubuwono $\mathrm{V}$ yang berisi sanjungan terhadap raja sekaligus menunjukkan unsur-unsur kepemimpinan dalam kesusastraan Jawa terdapat pada Serat Jatipusaka Makutharaja pupuh Sinom pada 2. Adapun kutipan kalimat tersebut:

\footnotetext{
Mulku kang nyakra buwana

iku tan kina ngendrani

bukari samsi narendra

sukahar retnadi murti

lan sindu upakaji

apiknya masbun amiru

yen jasaning arelala

byakta tan keneng nendraning

netepana asma sang makutharadi
}

Terjemahan:

Dikisahkan sang raja yang menjadi pemimpin

dimulai pada saat matahari terbit

sang raja berhiaskan permata yang indah dan hatinya merasa senang

raja yang menguasai dunia, raja yang agung tidak pilih kasih terhadap rakyat

raja yang menguasai dunia bagai matahari menerangi bumi

halus tutur bahasanya dan luhur budinya

(Dwiyanto, 2016: 189)

Tuntunan

nilai-nilai

kepemimpinan yang baik telah digariskan dalam agama dan terdapat di dalam kitab suci masing-masing (Suseno, 1997: 83). Moral merupakan nilai yang hakiki bagi manusia. Moral merupakan kesempurnaan manusia sebagai manusia, sedangkan kesusilaan merupakan tuntutan kodrat manusia (Drijarkara, 1978: 25). Manusia memiliki pengetahuan adanya baik dan buruk. Kesadaran moral merupakan pengakuan manusia mengenai baik dan buruk.

Pada tembang mijil dalam Serat Jatipusaka Makutharaja berisi gambaran mengenai etika kepemimpinan yang harus dimiliki oleh seorang raja. Sultan Hamengkubuwono V sebagai raja Kasultanan Yogyakarta 1822-1855 memiliki kekuasaan mutlak dalam bidang eksekutif, legislatif dan yudikatif. Karya sastra baik yang bersifat ciptaan baru, salinan maupun saduran tumbuh pesat pada masa kepemimpinan Hamengkubuwono V. Karya sastra sebagai panduan dalam pengembangan seni tari dan karawitan telah berhasil mendorong tumbu dan berkembangnya 
pementasan karya seni pertunjukkan (Dwiyanto: 2016, 190).

Pada masa kepemimpinan Hamengkubuwono V pementasan Wayang Wong gaya Mataram merupakan pertunjukkan yang paling banyak dipentaskan. Kehidupan sosial budaya pada waktu itu sangat berkembang hingga pada masa akhir pemerintahan. Sesuai dengan peristiwa yang melatarbelakanginya, kondisi sosial, politik, ekonomi, budaya, pertahanan dan keamanan masa pemerintahan Hamengkubuwono V sangat dinamis. Situasi yang terjadi di lingkungan kerajaan maupun di luar kerajaan menjadi ujian tersendiri bagi Sultan Hamengkubuwono V sebagai seorang pemimpin.

Ajaran dan pesan moral dalam masyarakat Jawa disampaikan melalui media seni, tembang, pitutur, piweling dan tembang oleh para orang tua secara turun temurun. Hal tersebut dapat dibuktikan dengan banyaknya sastra piwulang. Eksistensi dan moralitas dalam budaya Jawa dijunjung tinggi dibuktikan dengan ungkapan tradisional seperti becik ketitik ala ketara, titenana wong cidra mengsa langgenga dan sura dira jayaning lebur dening pangastuti. Dimensi sosial nilai-nilai etis memberikan suatu kadar objektif yang jarang ditemui pada bidang kreativitas yang bersifat pribadi (Dwiyanto, 2016: 91).

Dalam naskah Serat Jatipusaka Makutharaja memuat kutipan kitab yang terkenal dalam kesusastraan nusantara yaitu Kitab Tajussalatin. Bait-bait kitab tersebut berada diurutan ketujuh setelah Serat Surya Nalendra. Saduran kitab tersebut disajikan dalam pupuh Dhandhanggula. Tajussalatin yang berarti mahkota segala raja merupakan buku yang berisi pedoman seni memegang pemerintahan berdasarkan ajaran agama Islam. Buku tersebut aslinya berbahasa Persi ditulis oleh Bukhari al-Jauhari. Buku tersebut disalin dalam bahasa Melayu di Aceh pada tahun 1603 Masehi (Dipodjojo, 1999: ix).

Pada
selanjutnya kitab
Tajussalatin
diterbitkan dalam kajian ilmiah
seperti tesis, disertasi dan buku
tersendiri dalam tujuh buah versi.
Serat Tenajulssalatin secara garis
besar dikutip dalam kitab Jatipusaka
Makutharaja, seperti kitab

Tajussalatin yaitu uraian mengenai 24 fasal yang berhubungan dengan tugas dan tanggung jawab seorang raja, menteri, hulubalang dan juga rakyat. Adapun fasal yang terkait dengan kepemimpinan antara lain: Fasal kelima, mengenai martabat dan kekuasaan raja; Fasal keenam, mengenai keadilan dan menegakkan keadilan, Fasal ketujuh, mengenai budi pekerti raja yang adil; Fasal kedelapan mengenai raja yang kafir namun berlaku adil; Fasal kesembilan, mengenai kedzaliman dan penindasan; Fasal kesepuluh, mengenai tugas, kewajiban dan budi pekerti pembesar kerajaan; Fasal kesebelas, mengenai tugas dan kewajiban penulis kerajaan; Fasal ketujuh belas mengenai undangundang kerajaan dan Fasal kedua puluh mengenai hubungan hamba 
yang Islam terhadap rajanya (Dipodjojo, 1999: 8-9).

\section{Pada Serat Jatipusaka}

Makutharaja pupuh dhandhanggula pada 3 menjelaskan mengenai nilainilai kepemimpinan yang harus melekat pada seorang raja yang digambarkan memiliki hati yang luas, memiliki sifat bijaksana dan tidak menindas rakyat. Sebuah negeri/kerajaan akan selalu mendapat rahmat dari Yang Maha Kuasa apabila raja memiliki sifat-sifat tersebut. Adapun kutipan kalimat dalam tembang tersebut:

\section{Lamun mulku ingkang mangrenggani adil tajem sapernataning rat angantepi ubadile kinancar masbun tuhu dirga nireng nugraha jati mapan tinunggeng baya layaning Hyang Agung murcita tisning nugraha ing panjara mimbuhi kusla lokadi tama kadirun kusla sinipta kodrattolah}

Terjemahan:

Seorang raja yang bertahta

Adalah seorang yang adil dalam memimpin Memihak pada keadilan

Benar-benar memancarkan

Keselamatan bagi semua rakyat

Dapat menghindarkan rakyat dari bencana

Atas pertolongan Yang Agung

Sehingga mendapat anugerah

Sebab negara bukanlah penjara

Rakyat perlu mendapatkan keselamatan

(Dwiyanto, 2016: 201)

Dalam kutipan di atas berisi nasehat mengenai kepemimpinan, kemasyarakatan dan kesusilaan. Pada dasarnya etika tidak dapat menggantikan agama. Disisi lain etika juga tidak bertentangan dengan agama. Peran agama dan etika menjadi lebih penting guna mengimbangi perkembangan ilmu pengetahuan (Jacob, 1993: 30). Manusia hidup dalam norma-norma yang membatasi tingkah laku. Manusia dapat dipandang baik dari segi kesusilaan apabila telah memenuhi syarat-syarat dalam kesusilaan.

Moral atau kesusilaan merupakan nilai yang paling hakiki bagi manusia. Moral merupakan kesempurnaan manusia sebagai manusia, sedangkan kesusilaan merupakan tuntutan kodrat manusia (Drijarkara, 1978: 25). Manusia pada umumnya memiliki pengetahuan adanya baik dan buruk. Pengakuan manusia mengenai baik dan buruk dapat disebut sebagai kesadaran moral atau moralitas (Dwiyanto, 2016: 202).

Seorang raja juga diharapkan memiliki keterampilan, pandai bertutur kata, terbiasa dan terampil. Sebagai bisyara atau utusan Hyang Widi, raja selalu dipayungi oleh dzat kemuliaan Gusti yang menjelma dalam hatinya. Manusia dikatakan bermoral apabila tidak hanya mementingkan kebutuhan jasmani saja, melainkan juga kebutuhan rohani. Masyarakat Jawa menyebut ajaran moral dengan istilah unggah ungguh, suba sita, tata karma, tata susila, wulang wuruk, pranatan, pituduh, pitutur, wejangan, wursita, duga prayoga, wewaler dan pitungkas.

\section{KETERKAITAN KARYA SASTRA HEMENGKUBUWONO V DENGAN MASA KINI}


Nilai-nilai kepemimpinan yang tersurat dalam Serat Jatipusaka Makutharaja pada masa Hamengkubuwono V menggambarkan serangkaian kegiatan manusia dan pikiran yang dimiliki untuk digunakan dalam berbagai tata cara sehingga menghasilkan pengetahuan yang teratur mengenai gejala alami, kemasyarakatan dan perorangan demi mencapai kebenaran, pemahaman, memberikan penjelasan ataupun melakukan penerapan. Pengetahuan mengenai etik dan mistik juga terdapat dalam Serat Jatipusaka Makutharaja. Nilai etik dan mistik menyadarkan bahwa manusia dan alam merupakan kesatuan dengan hakekat ilahi. Dalam Serat Jatipusaka Makutharaja kesatuan antara Tuhan, manusia dan alam disebut dengan manunggaling kawula Gusti.

Dalam kebudayaan Jawa, konsep kesempurnaan memiliki penafsiran mengerti akan awal dan akhir kehidupan. Kesempurnaan dihayati dengan cipta, rasa dan karsa. Manusia dapat dikatakan sempurna apabila telah dapat mengerti dan menghayati awal dan akhir hidupnya. Apabila manusia telah tiada maka disebut telah bersatu dengan Sang Pencipta. Manusia sempurna memiliki kebijaksanaan dan kemampuan untuk mengetahui peristiwa-peristiwa di luar jangkauan ruang dan waktu (Ciptoprawiro, 1986: 82).

Sebagai karya Widyatama (etis filosofis), Serat Jatipusaka Makutharaja mengandung pengetahuan material lahiriah dan pengetahuan spiritual rohaniah. Serat
Jatipusaka Makutharaja merupakan salah satu karya sastra yang mengandung nilai etis yang dalam dan dapat memberi peluang melakukan pengkajian filosofis dan mistik. Pada dunia filsafat, gejala yang tampak menurut versi kejawen berbentuk perlambang pasemon.

Pengertian mengenai ilmu digambarkan dalam Serat Jatipusaka Makutharaja pupuh Maskumambang pada 2-3. Ilmu ketuhanan dalam kepustakaan Islam kejawen disebut ngelmu sangkan paran. Mengenal Tuhan berarti mengenal asal kejadian manusia sekaligus tempat kembali pada hari kemudian. Dalam kejawen, ilmu mengenai Tuhan sebagai sangkan paraning dumadi disebut dengan ngelmu kasampurnaan (Simuh, 1988: 364). Ngelmu kasampurnan berarti membuat hidup manusia menjadi sempurna. Dalam Serat Jatipusaka Makutharaja juga ditemukan pengertian ilmu dan manusia dalam menuntut ilmu.

Pada filsafat Islam wejangan mengenai ilmu kesampurnaan jiwa termasuk dalam ilmu kebatinan yang disebut sebagai tasawuf atau sufisme, sedangkan masyarakat Jawa menyebutnya dengan suluk dan mistik. Ajaran kejawen bukan termasuk dalam agama, namun merupakan suatu kepercayaan sebab di dalamnya terdapat ajaran-ajaran yang berdasarkan kepercayaan terhadap Tuhan dan sebagai falsafah hidup masyarakat Jawa. Dalam kepustakaan Islam kejawen, Tuhan dilukiskan memiliki sifat-sifat yang sama dengan manusia dan manusia digambarkan sama dengan Tuhan (Simuh, 1988: 299). 
Dalam Serat Jatipusaka Makutharaja pada 21 membahas mengenai keselarasan sosial yang kemudian melahirkan gelar-gelar yang dianggap memiliki kekuatan magis (Dwiyanto, 2016: 211). Ilmu pengetahuan yang diuraikan dalam bentuk ajaran moral kepemimpinan telah dapat menggambarkan arah ideologi kepemimpinan Hamengkubuwono V. Ideologi kepemimpinan tersebut merupakan perpaduan antara agama Islam dan budaya Jawa. Sebagai khalifah di bumi, manusia tidak boleh berpangku tangan tanpa berbuat apapun. Kelangsungan dan keseimbangan hidup bumi akan terjadi apabila masyarakat memiliki pola hidup dan sistem bermasyarakat yang sesuai.

Para raja Jawa sejak zaman dahulu selalu mengutamakan ilmu pengetahuan dalam menjalankan pemerintahan. Seiring perkembangan zaman, ilmu terus mengalami perkembangan. Namun demikian ilmu sebagai gejala yang makin nyata dalam kehidupan manusia terus dan makin dipersoalkan dan dipelajari. Ilmu merupakan pengetahuan yang tersusun sistematis. Ilmu pengetahuan membuat manusia berupaya untuk mendeskripsikan alam dan kehidupan sebagaimana adanya dengan tujuan menemukan penjelasan yang memungkinkan manusia untuk dapat meramalkan dan mengontrol objek tersebut (Suriasumantri, 1986: 17).

Serat Jatipusaka Maktharaja menjelaskan mengenai keberadaan manusia secara ontologis-metafisis, yaitu dari tiada menjadi ada, selanjutnya melaksanakan lakon, manut dan kembali menjadi tiada. Segala sesuatu telah diatur sebelum manusia dilahirkan. Dalam menjalankan kehidupan, manusia wajib untuk selalu berusaha, namun segala yang terjadi tetap Tuhan yang menentukan. Manusia diharapkan dapat berlalu dari alam 'nyata' menuju alam yang sunyata, dari alam realitas ke alam transendetal demi mencapai perkembangan pada diri menjadi sampurna. Adapun kutipan kalimat yang menggambarkan kenyataan tersebut terdapat pada Serat Jatipusaka Makutharaja, pupuh Sinom, pada 2:

Iku sakwakun pusaka rampungena kang tan mindho gaweni ingkeng memet nyamut-nyamut keng tajem dipermana ingkeng apik keng jolo ingkang kariun lejem unining wilapa tasri ngalam adi murti

Terjemahan:

Sebuah pusaka itu harus segera selesai jangan sampai dua kali yang nyata sangat jauh yang tajam sempuranakanlah yang bagus yang jolo bagaikan bunyi syair yang menyedihkan (Dwiyanto, 2016: 214)

Kutipan kalimat tersebut berisi ajakan bagi manusia untuk selalu bertakwa kepada Tuhan Yang Maha Esa. Manusia merupakan makhluk yang paling mulia. Manusia memiliki keistimewaan yang membawanya pada kedudukan sebagai khalifah. Manusia diberi wewenang untuk membangun dunia secara bersama-sama (Yafie, 1997: 32). 
Pada Serat Jatipusaka Makutharaja pupuh Sinom pada 7 menjelaskan mengenai kepemimpinan berbasis agama dan budaya, yaitu perpaduan kepemimpinan yang mengacu pada ajaran Islam dan dikemas dalam kerangka budaya Jawa. Adapun kutipan kalimat tersebut:

Yen tan wruh sampurneng sadat meksih kumprung kuncung lir bocah kucir sampurneng salat yen tan wruh padha meme ting tekad kudu wagna layan sampurnaning lampus padha meme ting penyipta yen tan wruh saparti gembring

Terjemahan:

Apabila belum mengerti sempurnanya syahadat masih bodoh seperti kuncung atau anak kecil belum sempurna salatnya jika tidak tahu mesti nyata tekadnya

harus tahu sempurnanya mati

mesti nyata dalam mencipta

jika tidak tahu seperti gembring

(Dwiyanto, 2016: 205)

Pada budaya Jawa, konsep keilmuan tidak hanya hasil pemikiran rasional saja, namun juga dari hasil pikiran (cipta), perasaan (rasa) dan kehendak (karsa). Keilmuan dalam budaya jawa mengenal istilah ilmu dan ngelmu. Ilmu memiliki serangkaian kegiatan olah otak manusia yang merupakan hasil penemuan dari berbagai ide/gagasan yang direfleksikan secara teoritis dan berdasarkan realitas. Ngelmu dalam ontologi budaya Jawa merupakan konsep yang tidak didukung oleh bukti yang rasional dan dapat dibuktikan secara rasional.

Metode yang digunakan dalam ngelmu yaitu melalui ketajaman penghayatan oleh hati dan rasa yang tersimpan di lubuk hati yang terdalam. Hasil yang dicapai adalah sumusup ing rasa jati untuk menangkap fenomena kehidupan dan proses pencapaian memerlukan bekal yang cukup dalam olah pengendalian diri. Aspek penting untuk memperoleh ngelmu antara lain madubasa (kedewasaan pribadi), madurasa (kedewasaan sosial) dan madubrata (kedewasaan spiritual).

Nilai-nilai kepemimpinan dalam budaya jawa membentuk kepribadian pemimpin untuk lebih menonjol yang dibentuk melalui interaksinya dengan budaya lingkungan, sehingga kepribadian seorang pemimpin tidak terlepas dari nilai budaya masyarakatnya. Dalam menjalani hidup, manusia akan menjalin kontak sosial budaya. Setiap manusia harus dapat berpartisipasi dalam kehidupan sosial, politik, ekonomi dan budaya melalui proses sosial (Dwiyanto, 2016: 218). Penjelasan mengenai seorang pemimpin yang ideal dalam memerintah rakyat terdapat dalam Serat Kalatidha pupuh Sinom pada 3:

Retune ratu utama

Patihe patih linuwih

Pra nayaka tyas raharja

Panengkere becik-becik

Terjemahan:

Rajanya raja utama

Patihnya patih mumpuni

Para aparat jujur-jujur

Pekerjaannya baik-baik

(Dwiyanto, 2016: 219)

Pada tembang mijil yang terdapat dalam Serat Jatipusaka Makutharaja menggambarkan mengenai etika kepemimpinan yang harus dimiliki oleh seorang raja. 
Seorang pemimpin harus mampu mengendalikan diri dari aktivitas emosi yang berlebihan. Berfikir sebelum bertindak menjadi acuan seorang pemimpin dalam melakukan suatu tindakan yang akan menghasilkan lebih banyak manfaat. Nilai-nilai kepemimpinan akan nampak ketika seorang pemimpin harus melakukan sesuatu yang jauh dari sifat-sifat tercela.

Sifat-sifat tercela yang dilakukan seorang pemimpin akan menjauhkan kewibawaan, ketauladanan dan sebagai panutan bagi bawahan. Keteladanan seorang pemimpin dalam menjalankan ibadah dan selalu menuntut ilmu dibuktikan dalam Serat Jatipusaka Makutharaja pupuh Dhandhanggula pada 9:

Aplalaning salat jati yen ngadeg amermanakna marang sirolah jatine sumunu neng tuwisika sumunnya lir kumala rukuk keng murciteng dulu mrang napasing jagat jala

Terjemahan:

Sehari-hari menjalankan

Salat lima waktu

Supaya hidupnya

Teratur dan terarah

Selalu mencari ilmu

Untuk menambah pengetahuan

Agar menjadi lebih bijaksana

(Dwiyanto, 2016: 224)

Raja yang dianggap mulia
adalah yang memiliki
kepemimpinan seperti
pewayangan Yudhistira
Seorang raja tidak boleh melupakan
bukari samsi narendra (asal usul

leluhur) dan nilai-nilai kemuliaan lain. Raja harus awas pada tajjali atau penampakan Allah dalam sifatsifat yang menyatu dalam hatinya, sehingga dapat melaksanakan tanggung jawab sebagai seorang pemimpin dengan benar, bersih dan adil. Sifat lain yang harus dimiliki oleh seorang raja yaitu sindu upaka (air jernih yang mengalir).

Seorang raja/pemimpin yang memiliki sikap tercela disebut sebagai raja yang tanajul makutharaja yang berarti raja yang tidak paham asal usul kehidupan manusia dan sakwakun kayatin serta asal usul penciptaan kehidupan atau asal usuling dumadi. Seseorang yang memiliki sifat eling lan waspada akan mendapatkan keberuntungan. Manusia yang beruntung adalah manusia yang sadar akan posisi dan perbuatan yang dilakukannya. Manusia harus tetap bersikap etis dan logis, walaupun dalam situasi kacau (Soetrisno, 2004: 38).

\section{PENUTUP}

Pada kondisi politik dan sosial yang kacau pada masa pemerintahan Hamengkubuwono V akibat serbuan tentara Inggris yang berusaha menanamkan kembali kekuasaannya, karya sastra mulai mengalami kebangkitan dengan adanya ciptaan baru, salinan maupun saduran. Hamengkubuwono V memberikan dukungan penuh pada perkembangan seni pada waktu itu. Salah satu karya yang menonjol pada waktu itu adalah karya sastra yang memuat nilai-nilai dan ajaran yang baik dan dapat dijadikan pedoman pada masa sekarang terutama untuk seorang pemimpin.. 
Pada Serat Jatipusaka Makutharaja disebutkan bahwa kepribadian seorang pemimpin disebut sebagai tajjali. Seorang pemimpin tidak boleh melupakan bukari samsi narendra (asal usul leluhur) dan sukahar retna adimurti (perwujudan kehendak mulia para leluhur). Kepemimpinan yang ideal juga ditulis dalam naskah Serat Jatipusaka Makutharaja. Selain memiliki kemuliaan hati, seorang pemimpin juga harus menguasai tanajul makutharaja sehingga hatinya akan disinari. Dalam agama Islam seorang pemimpin yang ideal adalah yang dapat awas dan waspada terhadap Allah dengan sifat-sifat yang menyatu dalam hatinya.

Ajaran-ajaran moral kepemimpinan yang terdapat pada karya-karya sastra masa Hamengkubuwono V dapat menjadi acuan bagi generasi saat ini. Sebab di dalamnya mengandung pesan-pesan moral yang baik terutama untuk para pemimpin pada zaman sekarang, sehingga diharapkan agar seorang pemimpin tidak memilih jalan yang salah dalam mengambil suatu keputusan dan dapat mengendalikan emosi. Dalam Serat Jatipusaka Makutharaja juga menjelaskan mengenai hubungan seorang raja/pemimpin dengan bawahan. Raja/pemimpin yang memiliki kebijaksanaan, keadilan dan selalu melakukan hal-hal terpuji, akan memiliki kewibawaan dimata rakyat.

\section{DAFTAR PUSTAKA}

Ciptoprawiro, A. 1986. Filsafah Jawa. Jakarta: Gramedia.
Drijarkara. 1978. Percikan Filsafat. Jakarta: Pembangunan.

Dipodjojo, AS. dan Daruni, E. 1999. Taju'ssalatin Mahkota RajaRaja Naskah Lengkap dalam Huruf Melayu-Arab beserta Alih Hurufnya dalam Huruf Latin. Yogyakarta: Lukman Offset.

Dwiyanto, D. 2016. Atribut Kepemimpinan Pada ArtefakArtefak Hamengkubuwono V: Sebuah Kajian Arkeologi Sosial. Disertasi. Pascasarjana Universitas Gadjah Mada.

Endraswara, S. 2006. Falsafah Hidup Jawa. Yogyakarta: Cakrawala.

Fudyartanta. 1974. Etika Intisari Filsafat Kesusilaan dan Moral. Yogyakarta: Warawidyani.

Haryanto, S. 1992. Pratiwimba Adiluhung Sejarah dan Perkembangan Wayang. Jakarta: Jambatan.

Jacob, T. 1993. Manusia Ilmu dan Teknologi. Yogyakarta: Tiara Wacana.

Lindsay, J. 1994. Kraton Yogyakarta. Jakarta: Yayasan Obor Indonesia.

Marsono, dalam Djoko Dwiyanto. 2004. "Sastra Kasultanan Yogyakarta", Hari Jadi Kota Yogyakarta. Yogyakarta: Dinas Pariwisata, Seni dan Budaya Kota Yogyakarta. 
Poerwodarminto. 1985. Kamus Umum Bahasa Indonesia. Jakarta: Balai Pustaka.

Purwodiningrat. 2009. "Benda Pusaka dan Alat-Alat Upacara di Keraton Yogyakarta", dalam Djoko Dwiyanto, ed. dkk., Ensiklopedi Kraton Yogyakarta. Yogyakarta: Dinas Kebudayaan Daerah Istimewa Yogyakarta.

Ricklefs, MC. 1995. A History of Modern Indonesia. London: Macmillan Education Ltd. Terjemahan oleh Dharmono Hardjowijono. Sejarah Indonesia Modern. Yogyakarta: Gadjah Mada University Press.

Setiadi, B. 2013. Bangsawan di Zaman Modern. Surakarta: Etnika Pustaka.

Simuh. 1988. Mistik Islam Kejawen Raden Ngabehi Ronggowarsito. Suatu Studi Terhadap Serat Wirid Hidayah Jati. Jakarta: UI Press.

Soetrisno. 2004. "Dimensi Moral dalam Syair Tembang Wayang Purwa. Disertasi. Yogyakarta: Pascasarjana Gadjah Mada.

Supeni, S. 2011. Kepemimpinan Sekolah Berbasis Budaya Jawa. Yogyakarta: Elmatera.

Suriasumantri, JS. 1986. Ilmu Dalam Perspektif: Sebuah Kumpulan Karangan Tentang Hakekat Ilmu. Jakarta: Gramedia.
Suseno, FM. 1986. Kuasa dan Moral. Jakarta: Gramedia.

Susetya, W. 2007. Ilmu Dari Hastabrata sampai Sastra Jendra Hayuningrat: Menguak Ilmu Makrifat dan Simbolisasi Perwatakan Dalam Khasanah Pewayangan. Yogyakarta: Kreasi Wacana.

Suyami. 2008. Konsep Kepemimpinan Jawa Dalam Ajaran Sastra Cetha dan Astha Brata. Yogyakarta: Kepel Press.

Teeuw, A. 1982. Khazanah Sastra Indonesia: Beberapa Masalah Penelitian dan Penyebarannya. Jakarta: Balai Pustaka.

Yafie, A. 1997. Teologi Sosial Telaah Kritis Persoalan Agama dan Kemanusiaan. Yogyakarta: Tiara Anisa. 